\title{
Anton Powell, Nicolas Richer (eds.), Xenophon and Sparta, The Classical Press of Wales, Swansea 2020, 378 pp.; ISBN 978-1-910589-74-8
}

The reviewed book is a collection of twelve papers, previously presented at the conference organised by École Normale Supérieure in Lyon in 2006. According to the editors, this is a first volume in the planned series dealing with sources of Spartan history. The books that follow this will deal with the presence of this topic in works by Thucydides, Herodotus, Plutarch, and in archaeological material. The decision to start the cycle from Xenophon cannot be considered as surprising; this ancient author has not only written about Sparta, but also had opportunities to visit the country, personally met a number of its officials (including king Agesilaus), and even sent his own sons for a Spartan upbringing. Thus his writings are widely considered as our best source to the history of Sparta in the classical age.

Despite this, Xenophon's literary work remains the subject of numerous controversies in discussions among modern scholars. The question of his objectivity is especially problematic and the views about the strong partisanship of Xenophon prevailed for a long time; allegedly, he was depicting Sparta and king Agesilaus in a possibly overly positive light, even omitting inconvenient information. ${ }^{1}$ In the second half of the 20th century such opinion has been met with a convincing polemic, clearly seen in the works of H. R. Breitenbach and Ch. Tuplin. ${ }^{2}$ The scholars began to pay attention to all the places in Xenophon's works where the picture of Sparta appears as ambiguous, even criticising this aspect. Texts in the revived volume deal with similar issues. What is interesting is how their authors are eager to stress the rather positive attitude of Xenophon towards Sparta.

The opening and extensive article by A. Powell (“'One Little skytalē': Xenophon, Truth-telling in His Major Works, and Spartan Imperialism," pp. 1-63) strongly defends this hypothesis. The author suggests that Xenophon's writings, to a large extent, were addressed to the Spartans themselves and mainly concerned their disputes. Thus, the ancient author not only depicts many situations in ways favourable to them but also suggests a particular policy. A critic of certain Spartiates' behaviour (especially the cases of abuse by commanders and harmosts, like Thibron) may serve this purpose. According

1 E.g. G. Busolt, Griechische Geschichte, vol. II, Gotha 1904, 696; M. Maclaren, On the Composition of Xenophon's Hellenica, AJPh 55, 1934, 123.

2 H. R. Breitenbach, Historiographische Anschauungsformen Xenophons, Freiburg 1950; id., Xenophon, RE IXA, 1567-1928; C. J. Tuplin, The Failings of Empire: A Reading of Xenophon Hellenica 2.3.117.5.27, Stuttgart 1993. 
to the paper, Xenophon appears as a politically engaged publicist, who advocates for a common armed effort of the Greek poleis, under Spartan command, against Persia.

The author of the second article (N. Richer, "The Lacedemonian Model in Xenophon's Non-historical Works (Excluding the Cyropaedia)," pp. 65-107) seeks Spartan references in the philosophical and practical treaties of Xenophon, especially in Memorabilia. He notes that the ancient writer rarely refers openly to Lacedaemonian examples. Instead, Xenophon acts more discretely, through lexical and conceptual similarities. We can observe this in cases of the usage of the term kalokagathia, and of the myth of Heracles as well as in the stressing of the importance of obedience to the law, and selfcontrol. At the same time, the modern scholar explains cases of Sparta's critic by the evolution of Xenophon's views. This is reflected in different works, written during different periods of the Athenian's life. All of that suggests that Sparta was a very important intellectual inspiration for him, both in a positive and negative way.

The text of G. Daverio Rocchi ("Xenophon's Portrayal of Sparta in the Hellenica, the Lakedaimonion Politeia, and the Agesilaos," pp. 109-127) remains in continuity with the predecessor. It concentrates on the historiographical part of Xenophon's corpus. A comparison of texts brings the scholar to the conclusion that the picture of Sparta in Hellenica stands out from the rest. He also suggests the gradual evolution of Xenophon's ideas, and that he was promoting certain political ideas (like Spartan isolationism, rejection of an expansive sea policy, reconciliation of Sparta and Athens, their joined hegemony in the Greek world, or respect for the autonomy of the smaller poleis, distinct in the latter part of Hellenica).

V. Azoulay ("Sparta and the Cyropaedia: The Correct Use of Analogies," pp. 129159) devotes his article to a complicated problem of Lacedaemonian references in the work about Cyrus' education. He polemicizes with the earlier opinion of Ch. Tuplin, who believes that these analogies are inconclusive and only of limited importance (in one case, we even see a comparison of Spartans with the Assyrians, who are shown in a clearly negative way in Cyropaedia ${ }^{3}$ ). According to the French scholar, we can find many more analogies between Sparta and Persia, both on the level of described institutions and models of behaviour. Moreover, he stresses the structural similarities between Cyropaedia and Lacedaemonion Politeia such as the criticism of the actual situation in both states at the end of the works. This suggests that Cyropaedia is a presentation of Cyrus as the model of an ideal ruler, rather than an appraisal of some political system.

In the next text, G. Cuniberti ("The Communication of History in Xenophon: The Art of Narration, the Control of Reception and Happiness," pp. 161-177) proposes a narratological stadium of Xenophon's writings, especially historiographical texts and $C y$ ropaedia. The author concentrates on the rhetorical strategies used by the Athenian. According to him, differences in the descriptions of similar themes in particular works may be explained by the desire to influence the reader and by the evolution of Xenophon's political ideas.

V. Gray ("Defining the Difference: Xenophon and Spartan Law," pp. 179-201) juxtaposes information about the Spartan political system presented in the different works

3 Xen. Cyr. IV. 2. 1. Cf. C. Tuplin, Xenophon, Sparta, and the Cyropaedia, in: A. Powell, S. Hodkinson (eds.), The Shadow of Sparta, London 1994, 134-135. 
of Xenophon. She stresses that the Lacedaemonion Politeia is a single work wherein the author underlines the role of Lycurgus in the shaping of the state. The scholar also compares the information present in Xenophon with various testimonies about arrangements in other poleis and comes to the conclusion that laws ascribed to Spartans were not exceptionally different. This suggests the credibility of the testimony in Xenophon, which was put into question at the beginning of the article.

E. David ("Xenophon and the Myth of Lykourgos," pp. 203-221) continues to some extent the reflections of V. Gray and focuses on the alleged founder of Spartan constitutional principles. He draws attention to the fact that Xenophon ascribes the formulation of Spartan principles to the Lycurgus alone. This remains in contrast with Herodotus, who speaks about receiving the rules from Delphi, or about using Cretan arrangements. David also emphasizes the idealisation of Lycurgus in Xenophon's work, and by this, he explains the lack of an assignment to the lawgiver such controversial things as krypteia or land division (which was problematic in the Sparta of the 4th c. as Cinadon's conspiracy indicates). Perhaps this ancient tradition about Lycurgus was shaped mostly by Xenophon himself.

E. Millender in her article ("Foxes at Home, Lions abroad: Spartan Commanders in Xenophon's Anabasis," pp. 223-259) deals with the issue of the image of Spartan commanders in Anabasis. She argues that it is often definitely negative (as in the cases of Clearchus, Cheirisophus, and Anaksibus). The criticism of Xenophon concerns both their attitude to subordinates and allies, as well as collusions between Spartans and Persians, problematic from the Panhellenic point of view. This suggests that Xenophon was not a blind admirer of Sparta. Probably, he was quite disappointed about her aggressive policy after the signing of the King's Peace (387/386), which led to the breaking of the autonomy of different poleis. The scholar also notes parallels with the critical remarks of Isocrates in Panegirycus.

T. J. Figueira ("Xenophon and the Spartan Economy," pp. 261-289) analyses the ancient author's views on the functioning of the economy (especially as presented in Oeconomicus and the treaty Ways and Means). He shows that Xenophon probably recognized, to some extent, the phenomenon identified today as the law of supply and demand. Next, he refers to these findings in the testimony of the Lacedaemonion Politeia, showing that the description of Sparta's economic basis is rather unsatisfactory, omitting the roles of helotes or perioici. The stressing of the role of restraint and self-control by Xenophon may have economic undertones.

N. Humble ("True History: Xenophon's Agesilaus and the Encomiastic Genre," pp. 291-317) compares the image of the Spartan king in Hellenica and Agesilaus. She concludes that the latter work should be perceived rather in categories of rhetoric (encomium) than historiography. This is confirmed by parallels between the Agesilaus and works of other authors (especially Isocrates) as well as recommendations of literature theorists (Aristotle). The Athenian himself probably was not a blind admirer of Agesilaus, as shown by his narrative in Hellenica, where we find critical remarks about the king. This raises a question (that according to the scholar must remain open) about the reasons why Xenophon decided to write an encomium.

The attitude of Xenophon to Agesilaus is also an object of research by P. Pontier ("Xenophon Presenting Agesilaos: The Case of Phleious," pp. 319-342). The scholar 
concentrates on two episodes present in Hellenica concerning Phleious. The first describes a Spartan intervention in 381 when a previously loyal ally was forced to change the political system and accept political exiles. Xenophon appears to partially justify the actions of Agesilaus as commander-in-chief, by underlining his care for his friends (philetairia) - in this case, local oligarchic dissidents. Later, he describes how Phleious maintained Sparta as a loyal ally during the Boeotian invasions on Peloponnese (in the '60s) and suggests that this was an effect of the earlier policy of Agesilaus.

J. Ducat ("Xenophon and the Selection of the hippeis (Lakedaimonion Politeia, 4.1-6)," pp. 343-360) deals with a picture of the elite hippeis, described in the Lacedaemonion Politeia. He points out that Xenophon focuses almost entirely on a single aspect of the formation's functioning: the brutal rivalry between young men aspiring to membership or frustrated by a rejection of their candidature. This testimony may be interpreted as an attempt to defend this procedure against the criticism of other Greeks. Xenophon had other ideas, presented in Cyropaedia, which suggest that he himself supported quite different solutions, ones that presumed a greater availability of elite education and training for the citizens.

The volume presents a comprehensive analysis of Sparta's presence in the whole corpus of Xenophon. It clearly shows that this polis played an important role in shaping his ideas and was a source of inspiration and examples (both positive and negative). Without a doubt, the holistic view on Xenophon (including his biography and his relationship with intellectual trends of the époque, especially Socratic philosophy) is a big advantage. It is also noteworthy that various authors in the book put a strong emphasis on Xenophon's own views, which he demonstrated in his texts. In this way, he becomes a much more vivid author, who not only described events in a more or less objective way but also tried to affect the minds of his readers. The scholars also attempt to define the circle of potential recipients of Xenophon's ideas. They do not doubt that he was thinking almost entirely about his contemporaries, in contrast to Thucydides, who declared that his work

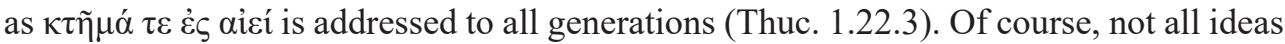
presented in the volume must be convincing for everyone. As the discussion of the last 200 years witnesses, the works of Xenophon have aroused controversies and probably will continue to do so in the future. Nevertheless, the reviewed book certainly presents opinions, that are worthy of consideration.

Wojciech Duszyński

iD http:/orcid.org/0000-0002-9939-039X Jagiellonian University in Kraków 